\title{
METODE SEMIOTIKA HUKUM JACQUES DERRIDA MEMBONGKAR GAMBAR LAMBANG NEGARA INDONESIA
}

\author{
Turiman $^{1}$
}

\begin{abstract}
Derrida as an example of post-structuralism, deconstruction tries to offer a method to solve problems of moderinitas. Target dekonstruksinya intended to dismantle the totalitarian nature of metaphysics and epistemology West has been dominated by logocentrism and the metaphysics of presence and should didekontruksi. Derrida deconstruction raid frees two concepts tyranny that dominates philosophy, the concept of totality and essence, so as to produce the plural truths, unique and relatively. Thus, diversity recognized. Difficulties faced Derrida is he going to stuck in the ambiguity that leads to nihilism. One of the most difficult to understand is that deconstruction strategy to parse the text. Deconstruction is a term used to describe a new sheet of philosophy, intellectual strategy, or models of understanding. Model understanding of deconstruction Derrida will be used in interpreting images Indonesia's national symbol under Government Regulation No. 66 Year 1951 About the State Emblem and Law No. 24 Year 2009 on the Flag, Language, and State Emblem and Anthem, with one fundamental question whether the drawing emblem The current state of Indonesia Garuda bird figure or figures Eagles?
\end{abstract}

Keywords: Derrida, deconstruction, eagle, hawk eagle

\begin{abstract}
Abstrak
Derrida sebagai contoh post strukturalisme mencoba menawarkan metode dekonstruksi untuk mengatasi problem moderinitas. Sasaran dekonstruksinya ditujukan untuk membongkar sifat totaliter dari metafisika dan epistemologi Barat yang selama ini didominasi oleh logosentrisme dan metafisika kehadiran sehingga harus di dekontruksi. Serangan dekonstruksi Derrida membebaskan dua konsep tirani yang mendominasi filsafat, yaitu konsep totalitas dan esensi, sehingga menghasilkan kebenaran yang plural, unik dan relatif. Dengan demikian, keberagaman diakui keberadaannya. Kesulitan yang dihadapi Derrida adalah dia akan terjebak dalam ambiguitas yang mengarah pada nihilisme. Salah satu yang paling sulit untuk dipahami adalah dekonstruksi yaitu strategi untuk mengurai teks. Dekonstruksi adalah sebuah istilah yang digunakan untuk menerangkan lembaran baru filsafat, strategi intelektual, atau model pemahaman. Model pemahaman dekonstruksi Derrida ini akan digunakan dalam menafsirkan gambar lambang negara Indonesia berdasarkan Peraturan Pemerintah Nomor 66 Tahun 1951 Tentang Lambang Negara dan
\end{abstract}

\footnotetext{
${ }^{1}$ Penulis adalah Staf Pengajar Fakultas Hukum Universitas Tanjungpura, Pontianak. Alamat kontak: turiman@untan.ac.id.
} 
Undang-Undang Nomor 24 Tahun 2009 Tentang Bendera, Bahasa, dan Lambang Negara serta Lagu Kebangsaan, dengan satu pertanyaan mendasar apakah gambar lambang negara Indonesia saat ini figur burung Garuda atau Figur Burung Elang?

Kata kunci: derrida, dekonstruksi, garuda, elang rajawali.

\section{Siapakah J .Derrida?}

Jaques Derrida lahir tahun 1930 di El Biar, dekat AlJazair dari ibu bapak keturunan Yahudi. Ia belajar di Ecole Normale Superieure dan akhirnya menjadi dosen tetap bidang filsafat di sekolah tersebut (1967-1992). ${ }^{2}$

Karya J.Derrida sangat banyak dan bisa dilacak dalam tulisan Albert Leventure dan Thomas Keenan dalam suntingan buku David Wood (1992) dengan judul Bibliography of the Works of Jaques Derrida. Diantara karya Derrida yang cukup terkenal antara lain: L'ecriture et la Diffrence (Tulisan dan perbedaan) (1967), De la Gramamtologie (Tentang Grammatologi),(1967), dan Marges de la Philosophie (1972) (Pinggiran-Pinggiran Filsafat)

Karya-karya J.Derrida hampir semua merupakan komentar atas filsuf dan ilmuwan lain, seperti Plato, Aristoteles, Kant, Hegel, Freud, Nietzche, Heidegger, dan Husserl. Dengan demikian pengaruh pemikiran tokoh-tokoh ini tidak bisa diabaikan. Sedangkan aliran pemikiran yang sangat mempengaruhinya adalah fenomenologi ${ }^{3}$ dan strukturalisme ${ }^{4}$, terutama fenomenologi Husserl dan Strukturalisme Saussure dan Levi Strauss.

\section{Pandangan Derrida Tentang Metafisika dan Epistemologi Modern}

\section{Kritik atas Metafisika Kehadiran dan Logosentrisme}

Usaha Derrida untuk merekonstruksi filsafat modern pertama-tama adalah dengan mengkritik pandangan metafisika dan epistemologi modernisme. Menurut Derrida, seluruh tradisi pemikiran Barat sangat 491.

${ }^{2}$ K. Bartens, "Filsafat Abab XX Jilid II: Perancis”, (Jakarta: PT Gramedia,1990), hal.

${ }^{3}$ Penomenologi - Phenomenology adalah sebuah gerakan filsafat abad ke 20 yang menonjol dalam metodenya yang cermat tanpa bias dalam melukiskan sifat-sifat (makna) universal dalam suatu subyek (fenomena) yang nampak dalam kesadaran , seperti aturan logis, nilai, perasaaan, ide, atau objek materiel. Para fenomenolog adalah anti reduksionis.

4 Strukturalisme (Structuralism) adalah gerakan intelektual yang berkaitan dengan penyingkapan struktural berbagai pemikiran dan tingkah laku manusia, yang prinsipnya adalah satu totalitas yang kompleks hanya dapat dipahami sebagai sesuatu perangkat unsur-unsur yang saling berkaitan. 
dipengaruhi oleh Kata, tanda atau konsep seakan-akan telah menunjuk atau menghadirkan being.

Pemikiran Barat selalu menunjukkan terjadinya pertarungan antara Mitos dan Logis. Pada zaman modern. Logis nampak menguasai pikiran manusia. Para filsuf berdebat tentang dasar-dasar, asas-asas, eidos, arche, telos, energeia, ousia (hakekat, eksistensi, subtansi, subyek) altheia, transendentalitas, kesadaran atau suara hati, Allah, manusia dan seterusnya. Mereka menganggap bahwa dengan berhasil menjelaskan konsep tersebut, berarti telah menguasasi realitas.

Derrida menolak pandangan tersebut, justru menurutnyab, tanda, kata atau (trace). "Bekas" akan hilang jika telah ada sesuatu yang menggantikannya."Bekas" merupakan teks yang terjalin dengan teks-teks yang lain. Menurut Derrida, tidaklah beralasan mengatakan bahwa kata, tanda dan konsep telah menghadirkan kenyataanj/ Derrida menyatakan bahwa dalam kenyataannya "yang ada" bersifat majemuk, tak berstruktur dan tak bersistem, sehingga tidak bisa sewenang-wenang direkayasa dalam kata, tanda atau konsep tunggal. Pandangan metafisika modern tersebut harus didekonstruksi (dibongkar) jika menginginkan solusi atas dilema modernitas.

Derrida memandang bahwa pandangan para filsuf Barat, dari Plato sampai Rousseau, Dari Descrates sampai Husserl, juga masih dikungkung atau "terbelenggu" oleh tradisi berpikir "logosentrisme". Logosentrisme artinya kepercayaan penuh pada logos atau rasio. Ciri yang menonjol dari tradisi logosentrisme ini adalah adanya kecenderungan berpikir oposisi biner yang bersifat hirarkis (esensi, eksistensi, substansi, aksiden, jiwa/badan, makna, bentuk, transenden/ empiris, positif/negatif, bahasa lisan/bahasa tulisan, konsep/metafor, dan seterusnya) dengan anggapan bahwa yang pertama merupakan pusat, asal muasal, fondasi, prinsip, dan ada secara niscaya; sedang yang kedua hanya derivasi, manefestasi pinggir, dan sekunder dalam kaitannya dengan yang pertama. ${ }^{5}$

Logosentrisme dicirikan dengan dominannya konsep totalitas dan konsep esensi. ${ }^{6}$ Konsep totalitas adalah ide yang menyatakan bahwa realitas adalah satu. Konsekuensinya adalah pengetahuan yang menindas, karena memaksa manusia masuk ke dalam sistem. Konsep esensi adalah konsep pengetahuan tentang yang mendasari sesuatu. Konsep ini menimbulkan dogmatisme dan meligitimasi kekuasaan rasio.

\footnotetext{
${ }^{5}$ Sahal, Ahmad, Kemudian dimanakah Emansipasi? Tentang Teori Kritis , Geneologi, dan Dekonstruksi, Dalam "Jurnal Kebudayaan KALAM", No 1 th 1994, Yayasan Kalam dan Penerbit Pustaka Grafiti, Jakarta, hal 19.

${ }^{6}$ A. Hendra Santoso, Postmodernisme: Kritik atas Sains dan Filsafat Modern, Dalam "Majalah Filsafat DRIYARKARA", Th. XIX, No. 4, 1992/1993, STF Driyarkarsa, Jakarta, hal 19.
} 
Contoh bentuk logosentrisme dapat dilihat dalam masyarakat kapitalis dunia yang orientasi-orientasi dan prosedur-prosedur praktisnya merupakan hasil pertautan rumit antara pengakuan dan kekuasaan kesewenangan. Menurut Derrida, logosentrisme sekurang-kurangnya mengandung dua ciri. Pertama, prosedur-prosedur yang ada harus diakui sebagai suatu orientasi yang paling umum. Kedua, prosedur-prosedur itu harus merupakan suara yang berdaulat yang tidak lagi dapat dipermasalahkan atau diperdebatkan. ${ }^{7}$ Ciri logosentrisme inilah yang dikritik oleh Derrida karena dianggap memunculkan ketimpangan dalam dunia modern.

\section{Kritik atas Epistemologi Modern}

Pandangan logosentrisme juga berimplikasi pada pandangan epistemologi modern yang dicirikan dengan dikhotomi subyek obyek. Ketika peranan subyek demikiam besar, obyek menjadi bahan eksploitasi bagi subyek. Subyek dengan rasionya menentukan validitas kebenaran. Metafisika kehadiran telah mempengaruhi pandanghan epistemologinya. Ciri yang paling menonjol adalah dominasi subyek dan kebenaran yang absolut, yaitu kebenaran yang tunggal, umum, universal. Kebenaran yang demikian sangat berbahaya, karena akan menjadi tempat persembunyian kepentingan kekuasaan antara pihak yang satu atas pihak yang lain.

Dalam perspektif Derrida, filsafat cenderung mencari kebenaran absolut, sehingga menunggalkan pengertian bahasa yang digunakan untuk menyusun konsep dan teori. Filsafat percaya bahwa konsep dan teori mampu mempresentasikan kebenaran seperti apa adanya. Oleh karena itu prkebaktis dan etika kehidupan publik manapun harus mendasarkan dirinya di atas konsep filosofis yang kuat klaim kesahihannya. Demikianlah yang diyakini para filsuf seperti Plato. Hegel, Marx dan Teori Kritis Mahzab Frankfurt.

Derrida menginginkan kebenaran itu tidak harus dibatasi dalam kebenaran tunggal, umum, dan universal, karena dalam kenyataannya kebenaran itu bersifat plural, partikular, dan relatif. Untuk merealisasikan gagasannya sekaligus kritiknya atas modernitas, Derrida mengungkapkannya dalm metode dekonstruksi.

\section{Bagaimana Metode Dekonstruksi Derrida ?}

Dalam mencermati masalah di atas, Derrida terggugah untuk bisa melakukan suatu dekonstruksi oposisi terhadap filsafat Barat. Dekonstruksi bisa diartikan sebagai pembongkaran, namun bukanlah pembongkaran atau penghancuran yang berakhir dengan pandangan

7 Hadiwinata, Bob Sugeng, Theatrum Politicum: Postmodernisme dan Kritis Kapitalisme Dunia, Dalam "Jurnal Kebudayaan KALAM", No. 1, Th 1994, Yayasan Kalam dan Penerbit Pustaka Grafiti, Jakarta, hal. 23. 
monisme atau bahkan kekosongan. Dekonstruksiu juga bukan metode tafsir yang dilengkapi dnegan perangkat-perangkat konseptual yang serba argumentatif dan koheren. Bahkan dekonstruksi justru anti metode, anti argumentasi, dan anti koherensi, karena pandangan ini berbau ilmiah dan positivistik.

Salah satu program dekonstruksi Derrida ditujukan kepada sejarah asal-usul yang begitu yakin akan pengenalan langsung terhadap realitas, kendati pengenalan kita selalu hanya berangkat dari "bekas" (trace) Disini, kita tidak lagi mengenali bekas sebagai sesuatu yang kemudian, melainkan menjadi awal. Konsep dekonstruksi merupakan hasil studinya mengenai sejarah sistematik filsafat, terutama pada filsafat fenomenologi Husserl dan Heidegger. Fenomenologi adalah filsafat tentang makna, di mana makna diasumsikan dapat diperoleh pada suatu wilayah yang pasti yang dapat dikenal langsung (unmediated). Karena wilayah ini dapat dikenal langsung, maka dengan sendirinya ia tampak sebagai suatu "kehadiran" (presence) pada persepsi kita. Bagi Husserl dengan dasar adana kehadiran ini, akan sangat memungkinkan ditemukan bentuk ekpresi murni realitas sebagai dunia penghayatan sehari-hari (lebenswelt). ${ }^{8}$

Derrida memulai deonstruksinya pertama kali dengan memusatkan perhatian pada bahasa sikap ini diambil mengingat ide, gagasan, konsep diungkapkan melalui bahasa. Bahasa dianggap telah mewakili realitas. Bahasa menjadi tempat persembunyian kepentingan. Bahasa menentukan prioritas suatu hal atas yang lain. Dalam padangan modernisme subyeksubyek, esensi-eksistensi, umum-khusus, absolut-relatif dan lain-lain menunjukkan bahwa kata pertama menjadi pusat, fondasi, prinsip, dan dominan atas kata berikutnya.

Dekonsruksi mencoba membongkar pandangan tentang pusat, fondasi, prinsip, dan dominasi tersebut sehingga berada dipimnggir. Strategi pembalikan ini dijalankan dalam kesementaraan dan ketidakstabilan yang permanen. Sehingga bisa dilanjutkan tanpa batas. Sungguh merupakan sebuah permainan yang serius. ${ }^{9}$ Strategi dekonstruksi dijalan dengan asumsi bahwa filsafat Barat bisa mempertahankan ide tentang pusat sebagai kehadiran murni hanya dengan cara menekan efek-efek metaforis dan figuratif yang menjadi karakter bahasa.

Penunggalan dibongkar dengan memunculkan kembali dimensidimensi metaforis dan figuratif dari bahasa dan membiarkan bahasa dalam karakternya semula, yaitu bersifat polisemi, ambigu, dan paradoks

\footnotetext{
${ }^{8}$ Tommy F. Awuy, "Problem Filsafat Modern dan Dekonstruksi", (Jakarta:Lembaga Studi Filsafat, 1993), hal. 23.

${ }^{9}$ Ahmad Sahal, Kemudian dimanakah Emansipasi? Tentang Teori Kritis , Geneologi, dan Dekonstruksi, Dalam "Jurnal Kebudayaan KALAM", No 1 th 1994, Yayasan Kalam dan Penerbit Pustaka Grafiti, Jakarta, hal. 19-20.
} 
bahasa dimunculkan kemebali, maka filsafat tidak hanya punya alasan untuk berkorespondensi dengan kebenaran. Filsafat tidak bisa lagi mengklaim dirinya memiliki otoritas kebenaran.

Derrida dengan ekstremnya mengatakan bahwa "sejarah filsafat Barat tidak lenih dari sejarah metafor (kiasan) dan metomini (pemakaian nama, benda yang berasosiasi atau menjadi atributnya, contoh: si kaca mata, si baju merah, dan lain-lain). ${ }^{10}$ Pandangan ini didukung oleh Lyotard yang menyebut filsafat ilmu-ilmu sosial modern sebagai grandnarrative (cerita agung) yang tidak lebih baik atau lebih buruk dari mitos. $^{11}$

Implikasi dahsyat dari dekonstruksi filsafat adalah pudarnya batasbatas antara konsep dengan metafor, antara kebenaran dengan fiksi, antara flsafat dengan puisi, dan antara keseriusan dengan permainan. Dengan membaca secara dekonstruksi, teks bisa dikatakan selama ini menjadi pusat yang dipinggirkan, dikeluarkan, dan dianggap sebagai: "yang lain". Namun menurut Derrida, "tidak ada sesuatu yang ada diluar teks", sehingga sang pusat juga tidak bisa mengklaim sebagai lebih dominan, karena ia hanyalah salah satu diantara jaringan teks. "Yang pusat" akan menyadari diri dalam konteks keberadaan "yang bukan pusat". Dalam aplikasinya, konsep esensi tidak harus mereduksi eksistensi, dan kebenaran umum tidak harus mengharuskan kebenaran partikular.

Pada perkembangan selanjutnya, dekonstruksi sering disalahpahmi hanya terbatas pada masalah cara membaca teks-teks sastar, filsafat, naskah-naskah kuno, atau sejenisnya. Jika pengertian dekonstruksi hanya dibatasi pada masalah tersebut, maka ide itu menjadi tidak produktif bagi emansipasi. Dekonstruksi hendaknya tidak dilepaskan dari tanggapan atas problem sosial, politik dan budaya, hukum yang mencari kemampanan dengan mengorbankan yang lain. Dekonstruksi digunakan sebagai strategi baru untuk memeriksa sejauhmana struktur-struktur yang terbentuk dan senantiasa dimapankan batas-batasnya serta ditunggalkan pengertiannya. Batas-batas penunggalan inilah yang disubversi oleh strategi dekonstruksi.

Keterlibatan Derrida dalam isu-isu etis politis ini ditunjukkannya dengan aktif menentang politik apatheid, menulis dukungan terhadap Mandela, ikut serta menentang usaha pemerintah Prancis untuk mengurangi ajaran filsafat di sekolah menengah, menjadi pengkritik yang vokal terhadap pelanggaran hak azasi manusia dan masuk dalam isu-isu feminisme. ${ }^{12}$

\footnotetext{
${ }^{10}$ Jacques Derrida, "L'ecriture et la Diffrence", terjemahan Alan Bass, Writing and Diffrence, (Chicago: The University of Chicago Press, 1978), hal. 277-278.

11 F. Hardiman, "Menuju Masyarakat Komunikatif: Ilmu Masyarakat, Politik dan Postmodernisme Jurgen Habermas”, (Yogyakarta: Kanisius 1993), hal. 10.
} 


\section{Refleksi Kritis dan Aktualisasi Dekonstruksi Derrida}

Pemikiran Derrida tersebut tidak terlepas dari kelebihan dan kekurangan. Refleksi tentunya harus mempertimbangkan konteks historis pemikiran Derrida. Derrida merupakan seorang komentator atas pemikiran filsuf lain seperti Plato, Aristoteles. Heidegger. Husserl, dan ilmuwan seperti Saussure dan Levi Strauss. Kritik Derrida yang dikemas dalam metode dekonstruksi terhadap pemikiran metafisika dan epistemologi modern, sebenarnya berakar pada logika Aristotelian. Aristoteles mengajarkan tiga prinsipium, yaitu (1) hukum identitas: "sesuatu hal sama dengan dirinya sendiri"; (2) hukum konstradiksi: "suatu hal, tidak mungkin benar dan salah pada saat yang sama"; (3) hukum penyisihan jalan tengah atau tidak ada jalan tengah:"segala sesuatu dinyatakan sebagai hal tertentu, atau tidak sama sekali”

Logika Aristoltelian telah mengungkung para pemikir Barat untuk mencari kebenaran tunggal, umum dan mutlak. Logika seakan-akan telah mewakili realitas. Dalam konteks seperti ini, Derrida telah berjasa dalam menyadarkan manusia tentang bahaya pemikiran tersebut. Derrida juga menyadarkan masyarakat modern bahwa modernisasi bukanlah satusatunya cara untuk memanusiakam manusia.

Kelebihan pemikiran Derrida adalah upayanya mencari pemikiran nilai alternatif ditengah nilai-nilai yang sudah ada. Hal ini akan memacu dinamika, serta merangsang manusia untuk mencari nilai lain yang "lebih baik", "lebih benar", "lebih mendalam", serta bisa menjawab problem dasar kemanusiaan. Pengaruh Derrida bagi pemikiran filsafat utamanya bertujuan untuk menyadarkan dan sebagai juru bicara bagi mereka yang selama ini dipinggirkan, diasingkan, dan yang menginginkan pluralitas, kebenaran relatif dan keunikan dalam mendapatkan tempat bernaung. Usaha Derrida ini sejalan dengan Foucault yang mencoba menganalisis keterkaitan pengetahuan dengan kekuasaan dalam bukunya The Archeology of Knowledge, juga Wittgenstein dengan Language Gamesnya.

Kelemahan yang sering dikritikkan terhadap pemikiran Derrida adalah sifat paradoks, konstrakdiksi, inkontensi, ambivalensi, dilematik dan tidak pasti. Pemikiran Derrida juga bersifat ambigu, artinya jika dia mengkritik suatu model pemikiran, maka dia akan terjebak menyusun model lain. Padahal model yang dikritk seperti inilah yang telah mendominasi pemikiran pihak lain. Namun, bila ia tidak menawarkan suatu model pemikiran, maka dia akan terjebak ke dalam nihilisme atau kekosongan. Sehingga kritik yang sangat pedas terhadap pemikiran Derrida dan pemikir postmodernisme dan poststrukturalisme pada awalnya meerupakan strategi dari dekonstruksi ini dimaksudkan untuk

\footnotetext{
${ }^{12}$ Ahmad Sahal, Op. Cit., hal. 19.
} 
mencegah totalitarianisme pada segala sistem, namum akhirnya cenderng jatuh kedalam relaitivisme dan nihilisme. ${ }^{13}$

Pemikiran sangatlah relevan untuk menganalisis kebhinekaan yang ada di Indonesia. Kebhinekaan ini tidak harus dikalahkan dengan konsep tunggal yang mampu merangkum segenap fenomena yang ada. Dalam perspektif Derrida, kebhinekaan senantiasa dipelihara dengan kesadaran, bahwa masing-masingf unsur merupakan teks, yang tergantung dan terkait dengan teks yang lain. Ajaran Derrida tentunya akan berbahaya jika diterapkan tanpa mengetahui landasan filosofisnya. Hal yang patut diambil dari dekonstruksi Derrida adalah semangat menghargai pluralitas dan keberadaan yang lain. Semangat ini harus dipupuk dalam dunia ilmiah maupun aspek budaya lainnya.

\section{Semiotika Dekonstruksi Derrida dalam penafsiran hukum.}

\section{a. Jacques Derrida \& Teori Model Semiotika Dekonstruksi}

Derrida terkenal dengan model semiotika Dekonstruksi-nya. Dekonstruksi, menurut Derrida, adalah sebagai alternatif untuk menolak segala keterbatasan penafsiran ataupun bentuk kesimpulan yang baku. Konsep Dekonstruksi yang dimulai dengan konsep demistifikasi, pembongkaran produk pikiran rasional yang percaya kepada kemurnian realitas pada dasarnya dimaksudkan menghilangkan struktur pemahaman tanda-tanda (siginifier) melalui penyusunan konsep (signified).

Dalam teori Grammatology, Derrida menemukan konsepsi tak pernah membangun arti tanda-tanda secara murni, karena semua tanda senantiasa sudah mengandung artikulasi lain

Dekonstruksi, pertama sekali, adalah usaha membalik secara terus-menerus hirarki oposisi biner dengan mempertaruhkan bahasa sebagai medannya. Dengan demikian, yang semula pusat, fondasi, prinsip, diplesetkan sehingga berada di pinggir, tidak lagi fondasi, dan tidak lagi prinsip. Strategi pembalikan ini dijalankan dalam kesementaraan dan ketidakstabilan yang permanen sehingga bisa dilanjutkan tanpa batas.

Sebuah gereja tua dengan arsitektur gothic di depan Istiqlal bisa merefleksikan banyak hal. Ke-gothic-annya bisa merefleksikan ideologi abad pertengahan yang dikenal sebagai abad kegelapan. Seseorang bisa menafsirkan bahwa ajaran yang dihantarkan dalam gereja tersebut cenderung 'sesat' atau menggiring jemaatnya pada hal-hal yang justru bertentangan dari moral-moral keagamaan yang seharusnya, misalnya mengadakan persembahan-persembahan berbau mistis di altar gereja, dan sebagainya.

13 I. Bambang Sugiharto, "Postmodernisme Tantangan bagi Filsafat", (Yogyakarta: Kanisius, 1996), hal. 31 . 
Namun, Ke-gothic-an itu juga dapat ditafsirkan sebagai 'klasik' yang menandakan kemurnian dan kemuliaan ajarannya. Sesuatu yang klasik biasanya dianggap bernilai tinggi, 'berpengalaman', teruji zaman, sehingga lebih dipercaya daripada sesuatu yang sifatnya temporer.

Di lain pihak, bentuk gereja yang menjulang langsung ke langit bisa ditafsirkan sebagai 'fokus ke atas' yang memiliki nilai spiritual yang amat tinggi. Gereja tersebut menawarkan kekhidmatan yang indah yang 'mempertemukan' jemaat dan Tuhan-nya secara khusuk, semata-mata demi Tuhan. Sebuah persembahan jiwa yang utuh dan istimewa.

Dekonstruksi membuka luas pemaknaan sebuah tanda, sehingga makna-makna dan ideologi baru mengalir tanpa henti dari tanda tersebut. Munculnya ideologi baru bersifat menyingkirkan ("menghancurkan" atau mendestruksi) makna sebelumnya, terusmenerus tanpa henti hingga menghasilkan puing-puing makna dan ideologi yang tak terbatas.

Jadi secara ringkas Teori Jacques Derrida, dapat dipaparkan, bahwaDerrida memperkenalkan model semiotika dekonstruksi. Dekonstruksi ini merupakan sebuah alternatif untuk menghilangkan segala keterbatasan penafsiran atau penyimpulan yang baku. Konsep ini membongkar produk pemikiran rasional yang mempercayai kemurnian realitas. Dekonstruksi memungkinkan sebuah tanda untuk ditafsirkan seperti apa saja, tidak ada batasan dalam pemaknaan. Luasnya pemaknaan sebuah tanda membuka peluang bagi lahirnya makna-makna dan ideologi baru yang tidak terbatas dari sebuah tanda. ${ }^{14}$

\section{b. Semiotika sebagai metode Penelitian}

Semiotika adalah metode penelitian untuk menafsirkan makna dari suatu pesan komunikasi baik yang tersirat (tertulis) maupun yang tersurat (tidak tertulis). Makna yang dimaksud mulai dari parsial hingga makna komprehensif. Sehingga dapat diketahui motif komunikasi dari komunikatornya.

Pemaknaan simbol dapat menggunakan analisis denotatif dan konotatif atau nilai-nilai ideologis atau mitologis dalam istilah Roland Barthes dan analisis kultural. Dengan perkataan lain metode semiotika dikembangkan untuk menafsirkan simbol komunikasi sehingga dapat diketahui bagaimana komunikator mengkontruksi pesan untuk maksud-maksud tertentu

Melalui analisis semiotika dapat dikupas tanda dan makna yang diterapkan pada sebuah naskah atau file dokumen sebagai bahan penelitian. Yang dimaksud naskah dalam penelitian semiotika adalah 
seluruh teks yang ada didalam naskah. Naskah dapat berupa karya manusia, seperti, novel, film, iklan, pidato, simbol/lambang kenegaraan-lambang-lambang pemerintahan daerah, lukisan, teks hukum dalam naskah peraturan perundang-undangan suatu negara.

Hasil analisis rangkaian tanda itu dapat menggambarkan konsep pemikiran, dan rangkaian tanda yang terinterpretasikan dari hasil analisis semiotika dengan menggunakan metode semiotika, kemudian menjadi jawaban atas pertanyaan nilai-nilai ideologi dan kultural yang berada dibalik sebuah naskah atau file dokumen, dalam hal penelitian ini dokumen file lambang negara yang menjadi bahan kajian penelitian ini

Simbol merupakan tanda berdasarkan konvensi, peraturan, atau perjanjian yang disepakati bersama. Simbol baru dapat dipahami jika seseorang sudah mengerti arti yang telah disepakati sebelumnya. Contohnya: Rajawali Garuda Pancasila bagi bangsa Indonesia adalah burung yang memiliki perlambang yang kaya makna. Namun bagi orang yang memiliki latar budaya berbeda, seperti orang Eskimo, misalnya, Rajawali Garuda Pancasila hanya dipandang sebagai burung elang biasa.

Kode, merujuk terminologi sosiolinguistik ialah variasi tutur yang memiliki bentuk yang khas, serta makna yang khas pula. Sementara itu, kode menurut Piliang, adalah cara pengkombinasian tanda yang disepakati secara sosial, untuk memungkinkan satu pesan disampaikan dari seseorang ke orang lainnya. Di dalam praktik bahasa, sebuah pesan yang dikirim kepada penerima pesan diatur melalui seperangkat konvensi atau kode. Umberto Eco menyebut kode sebagai aturan yang menjadikan tanda sebagai tampilan yang konkret dalam sistem komunikasi.

Fungsi teks-teks yang menunjukkan pada sesuatu (mengacu pada sesuatu) dilaksanakan berkat sejumlah kaidah, kesepakatan, dan kaidah-kaidah alami yang merupakan dasar dan alasan mengapa tanda-tanda itu menunjukkan pada isinya. Tanda-tanda merupakan sebuah sistem yang dinamakan kode.

Kode pertama yang berlaku pada teks-teks ialah kode bahasa yang digunakan untuk mengutarakan teks yang bersangkutan. Kode bahasa itu dicantumkan dalam kamus dan tata bahasa. Selain itu, teks-teks tersusun menurut kode-kode lain yang disebut kode sekunder, karena bahannya ialah sebuah sistem lambang primer, yaitu bahasa. Sedangkan struktur cerita, paparan, bentuk-bentuk argumentasi, sistem metrik, itu semua merupakan kode-kode sekunder yang digunakan dalam teks-teks untuk mengalihkan arti atau memahami sesuatu dibalik teks-teks yang menjadi bahan kajian atau analisis secara semiotika, sehingga berubah menjadikan kodekode tersebut sebagai kode primer. Dalam penelitian struktur lambang negara ditelaah/dianalisis melalui analisis semiotika menjadi tiga konsep simbolisasi (Pilihan burung, Perisai Pancasila, 
dan Frase Bhinneka Tunggal Ika) yang perlu dianalisis satu persatu makna denotatif maupun makna konotatif sebelum dipilih menjadi simbol kenegaraan dan dijadikan satu kesatuan simbol yang tidak terpisahkan tetapi terbedakan sehingga memenuhi prinsip-prinsip ilmu semiotika.

Bagaimana keabsahannya atau validitas sebuah teks dalam penelitian semiotika. Mengenai validitasnya dapat ditinjau dari: (1) keterlibatan, artinya seberapa besar keterlibatan peneliti pada obyek yang diteliti sesuai fokus penelitian yang dipilih. Sebanyak apa pengalaman penelitian sesuai naskah yang dianalisis. Apabila keterlibatan dan pengalaman yang cukup dapat diduga penafsiran didukung oleh data dan deskriptip, narasi serta argumentatif yang kuat. (2) Ketekunan, artinya memperkirakan semua aspek dalam proses pemaknaan teks. Memperhatikan semua aspek dan konteks, kontektualisasi dari suatu teks. Pemaknaan dapat dilakukan berdasarkan perspektif dari berbagai bidang keilmuan yang dipilih peneliti dengan berbagai multi pendekatan penelitian biasa lebih khusus pada tipe penelitian kualitatif. (3) Peneliti apakah melakukan trainggulasi data, baik triangulasi metode maupun tringulasi sumber data, misalnya dengan menggunakan teks lain yang obyeknya sama, membandingkan penafsiran dengan penafsiran lain dari berbagai sumber penafsiran. Mengeksplorasi teks dengan sejumlah keterangan verbal dalam berbagain literatur penelitian yang berkaitan dengan obyek penelitian atau fokus penelitian yang dipilih oleh peneliti. Jika hasil analisisnya berbeda, maka ajukan pertanyaan selanjutnya mengapa terjadi perbedaan dan mencari penjelasan pembanding yang mungkin ada penjelasan lain atau penjelasan baru, jika ada seberapa sahih penjelasan baru tersebut didukung data. (4) Uraian rinci, artinya seberapa rinci teks dianalisis. Semakin rinci dan sistimatis paparan hasil analisis, yaitu deskriptif, naratif, argumentatif serta menghasilkan pernyataan baru, maka semakin berkualitas penelitian semiotikanya.

\section{c. Penerapan Teori Semiotika Dalam Penelitian Kualitatif}

Dalam khasanah kebudayaan dan peradaban manusia, hadirnya ilmu semiotika dapat dikatakan mampu memberikan kerangka analisis yang lebih komprehensif. Sebagai ilmu yang mengkaji tentang tanda-tanda, semiotika oleh para pendukungnya diklaim dapat diterapkan disemua bidang kehidupan yang berbeda. Dari sini, semiotika termasuk dalam ilmu yang imperialistik, yakni dalam kemampuannya untuk memayungi analisis terhadap bidang yang berbeda. Namun, dari segi aksebilitasnya semiotika cukup menggugah para analis untuk berbuat lebih dengan memasuki relung-relung relasi yang tersembunyi dari sebuah fenomena. 
Fenomena kehidupan manusia sesungguhnya tak bisa dipisahkan dengan fenomena hukum, karena hukum secara semiotika dipahami sebagai simbol yang terpaparkan dalam teks hukum tertulis dalam bentuk formulasi atau rumusan bahasa yang dikenal dengan bahasa hukum. Bahasa hukum sejatinya didalamnya tersembunyi sesuatu hal yang tersirat dan tersurat. Tentunya untuk memahami terdapat berbagai metode penafsiran yang tersedia, tetapi akan lebih menarik dan holistik jika dipahami dengan analisis dari perspektif semiotika.

Beberapa ahli semiotika bahkan mengatakan bahwa semiotika adalah satu disiplin utama yang dapat dipakai untuk menerangkan setiap aspek dalam komunikasi dan tentunya termasuk dalam lintas komunikasi hukum. Memang jika belum paham semiotika adalah ilmu yang sangat rumit.Ia memiliki terminologinya sendiri. Dan agar menjadi semiotisi dan analisis yang holistik, tentunya kita harus mempelajari sesuatu dari tanda sebagai bagian dari semiotika.

Charles Sander Pierce, salah seorang pendiri semiotika, pernah berkata "...dunia ini bertaburan dengan tanda-tanda, jika tidak tersusun dari tanda-tanda yang ekslusif'. Oleh karenanya, amat logis bagi kita untuk memahami apakah tanda-tanda itu dan bagaimana mereka berfungsi. Ahirnya manfaat dari semiotika adalah untuk menggali dan mengerti tentang sesuatu dari tanda-tanda yang menarik dan mengandung petunjuk tentang kita sendiri sebagai manusia.

Sesungguh Tuhan Yang Maha Esa telah memaparkan proposisi ilahiahnya hal yang berkaitan dengan tanda-tanda sesuatu di alam raya dan tanda-tanda di dalam diri manusia. Didalam surah Fuhshilat (yang dijelaskan) (41) ayat 53 menyatakan "Kami akan memperlihatkan kepada mereka tanda-tanda Kami di segenap alam raya dan pada diri mereka sendiri, sehingga jelaslah bagi mereka bahwa Al-Quran itu adalah benar.Dan apakah Tuhanmu tidak cukup bagimu sesungguhnya Dia menyaksikan segala sesuatu ?’. Demikian juga pada surah Adz Dzaariyaat (Anging Yang Menerbangkan) 51 ayat 20, 21 menyatakan: "Dan dibumi itu terdapat tanda-tanda bagi orang-orang yang yakin, dan juga pada dirimu sendiri.Apakah kamu tiada memperhatikan?"

Pertanyaannya adalah apakah tanda itu ? Secara semiotika tanda adalah sesuatu yang terdiri pada sesuatu yang lain atau menambah dimensi yang berbeda pada sesuatu, dengan memakai apapun yang dapat dipakai untuk mengartikan sesuatu hal lainnya. ${ }^{15}$ Tanda-tanda itu seperti lembaran kertas.Satu sisi adalah penanda dan pada sisi yang lain menjadi petanda dan kertas itu sendiri adalah tanda. C.S

15 Arthur Asa Berger, "Semiotika Tanda-Tanda Dalam Kebudayaan Kotemporer", (Yogyakarta: Tiara Wacana, 2010), hal. 1. 
Pierce menyebut tanda sebagai "sesuatu pegangan seseorang akibat keterkaitan dengan tanggapan atau kapasitasnya". 16

Pertanyaan berikutnya adalah bagaimana kategorisasi tanda? Secara konstruksi teoritik, konsep tanda menurut Charles Sanders Peirce, dapat dijelaskan secara konsepsional. Tanda diklasifikasikan ke dalam tiga jenis berdasarkan relasi antara tanda sebagai representan dengan denotatumnya yaitu: ${ }^{17}$

1) Simbol yaitu tanda yang dapat melambangkan atau mewakili sesuatu (ide, pikiran, perasaan, benda, dan tindakan) secara arbitrer dan konvensional. Misalnya, warna merah dan putih dalam bendera kebangsaan Indonesia masing-masing melambangkan keberanian dan kesucian.

2) Indeks yaitu tanda yang dapat menunjukkan sesuatu (ide, pikiran, perasaan, benda, dan tindakan) secara kausal atau faktual. Misalnya, asap menunjukkan adanya api.

3) Ikon yaitu tanda yang dapat menggambarkan sesuatu (ide, pikiran, perasaan, benda, dan tindakan) berdasarkan persamaan atau perbandingan. Misalnya, potret menggambarkan orangnya.

Relasi antara tanda sebagai representan dengan denotatum di atas didasarkan pada sifat hubungan itu sendiri. Apabila hubungan antara tanda atau representan dengan denotatum atau objek melambangkan atau mewakili secara arbitrer dan konvensional, tanda itu disebut simbol; apabila menunjukkan secara kausal dan faktual, tanda itu disebut indeks; dan apabila menggambarkan berdasarkan persamaan atau perbandingan, tanda itu disebut ikon.

Proses penyampaian simbol itu disebut tindak komunikasi. Dengan kata lain, tanda (simbol, indeks, dan ikon) adalah media komunikasi (mediums of communication) yang berpijak dalam bidang semiotika. Untuk lebih jelasnya dapat dilihat gambar di bawah ini. Lingkaran pertama (paling dalam) menyatakan isi atau kandungan tanda, lingkaran kedua menunjukkan bahwa isi tanda itu dapat ditransformasikan ke dalam tiga jenis tanda, lingkaran ketiga menunjukkan bahwa tanda-tanda itu dapat juga diklasifikasikan ke dalam jenis tanda pada lingkaran kedua, dan lingkaran keempat menunjukkan bahwa tanda yang terdiri atas simbol, indeks, dan ikon merupakan bidang semiotik dan dapat digunakan dalam komunikasi.

${ }^{16}$ C.F. Pierce, "The Collected Paper of C.S Pierce”, vol 1-6, Charles And Paul Weiss (eds), 1931-5-8.A.W., Burks, (ed), (Cambridge: Harvard University Press, 1958), halaman 228.

${ }^{17}$ Charles Sanders Peirce, "Logic and Semiotics The Theory Of Signs",1955, p. 102, "The Fhilosophy Of Peirce; Selected Writing”, Ed.J.Buchler, London Routledge and Kegan Paul, 1956, p. 99-275 lihat juga Robert Sibarani, "Hakekat Bahasa", (Bandung : PT Aditya Bakti, 1992), hal. 15. 
Untuk menjelaskan paparan Charles Sanders Peirce diatas, kita pahami proposisi Pierce berkaitan dengan teori tanda:

Suatu analisis tentang esensi tanda...mengarah pada pembuktian bahwa setiap tanda ditentukan oleh objeknya. Pertama,ketika saya menyebut tanda suatu ikon, maka suatu tanda akan mengikuti sifat objeknya.Kedua, ketika saya menyebut tanda suatu indeks,kenyataan dan keberadaan tanda itu berkaitan dengan objek individual.Ketiga,ketika saya menyebut tanda suatu simbol, kurang lebih hal itu diinterpresentasikan sebagai objek denotatif lantaran adanya kebiasaan (istilah yang saya gunakan untuk mencakup sifat alamiah). ${ }^{18}$

Tabel berikut ini menjelaskan hal proposisi Pierce di atas:

Tabel 1

Konstruksi Teori Charles Sanders Peirce (1839 - 1914) Teori Segitiga Makna (Triangle Meaning)

\begin{tabular}{|c|c|c|c|}
\hline Tanda & Ikon & Indeks & Simbol \\
\hline $\begin{array}{l}\text { Ditandai } \\
\text { dengan }\end{array}$ & $\begin{array}{l}\text { Persamaan } \\
\text { (kesamaan) }\end{array}$ & Hubungan kausal & Konvensi \\
\hline Contoh: & $\begin{array}{l}\text { Gambar- } \\
\text { gambar, Patung- } \\
\text { Patung, Fhoto } \\
\text { Seseorang }\end{array}$ & $\begin{array}{l}\text { Asap/Api. } \\
\text { Gejala/penyakit } \\
\text { (bercak merah } \\
\text { campak) }\end{array}$ & $\begin{array}{l}\text { Kata-Kata, } \\
\text { Isyarat, Lambang- } \\
\text { Lambang, Tanda } \\
\text { Lalu Lintas }\end{array}$ \\
\hline Proses: & Dapat dilihat & $\begin{array}{c}\text { Dapat } \\
\text { diperkirakan }\end{array}$ & $\begin{array}{l}\text { Harus dipahami } \\
\text { dan dipelajari. }\end{array}$ \\
\hline
\end{tabular}

Berdasarkan tabel di atas, maka semiotika boleh berhadapan dengan genre apa pun. Ia boleh untuk memberikan penilaian yang adil dan seksama. Teori Semiotika beranggapan bahwa sebuah karya itu mempunyai sistemnya yang tersendiri, di mana, ia dapat diperlihatkan melalui sistem tanda dan kode yang terjelma di dalamnya. Oleh karena yang demikian, proses penciptaan yang melahirkan sistem karya itu juga menjadi objek penelitian. Ini termasuk sistem di luar karya yang dibawa masuk ke dalam karya;

${ }^{18}$ C.S Pierce dikutip oleh J.Jay Zenon, "Pierce's Theory of Sign" dalam T.Siboek, A Perfusin of Sign, 1977, hal. 36. 
atau lebih tepat lagi kebudayaan seluruh masyarakat yang menjadi sumber inspirasi pengkaryaan tersebut.

Terdapat beberapa pengertian asas tentang perlambangan yang dikemukakan di kalangan ahli tokoh-tokoh semiotika terutama dalam bidang linguistik dan kesusasteraan umum. Sebagaimana yang telah dijelaskan sebelum ini, teori semiotik ini sangat luas dan dipelopori oleh beberapa tokoh dengan ruang lingkup yang berbeda-beda. Maka, dalam dalam penelitian konsep semiotika Charles Sansder Pierce akan mudah digunakan. Dengan itu, prinsip-prinsip yang seperti ikon, indeks dan simbol mudah dibedakan antara yang satu dengan lain.

Pengertian simbol atau lambang adalah sesuatu yang dapat melambangkan mewakili ide, pikiran, perasaan, benda, dan tindakan secara arbitrer, conventional, dan representatif-interpretatif. Dalam hal ini, tidak ada hubungan langsung dan alamiah antara yang melambangkan (menyimbolkan) dengan yang dilambangkan (disimbolkan). Dengan demikian, baik yang batiniah (inner) seperti perasaan, pikiran, ide maupun yang lahiriah (outer) seperti benda dan tindakan dapat dilambangkan atau diwakili simbol. ${ }^{19}$

Proses penyampaian simbol itu disebut tindak komunikasi. Dengan kata lain, tanda (simbol, indeks, dan ikon) adalah media komunikasi (mediums of communication) yang berpijak dalam bidang kajian semiotika. Untuk lebih jelasnya dapat dilihat gambar di bawah ini. Lingkaran pertama (paling dalam) menyatakan isi atau kandungan tanda, lingkaran kedua menunjukkan bahwa isi tanda itu dapat ditransformasikan ke dalam tiga jenis tanda, lingkaran ketiga menunjukkan bahwa tanda-tanda itu dapat juga diklasifikasikan ke dalam jenis tanda pada lingkaran kedua, dan lingkaran keempat menunjukkan bahwa tanda yang terdiri atas simbol, indeks, dan ikon merupakan bidang semiotik dan dapat digunakan dalam komunikasi.

Berikut ini ragaan penjelasan diatas:

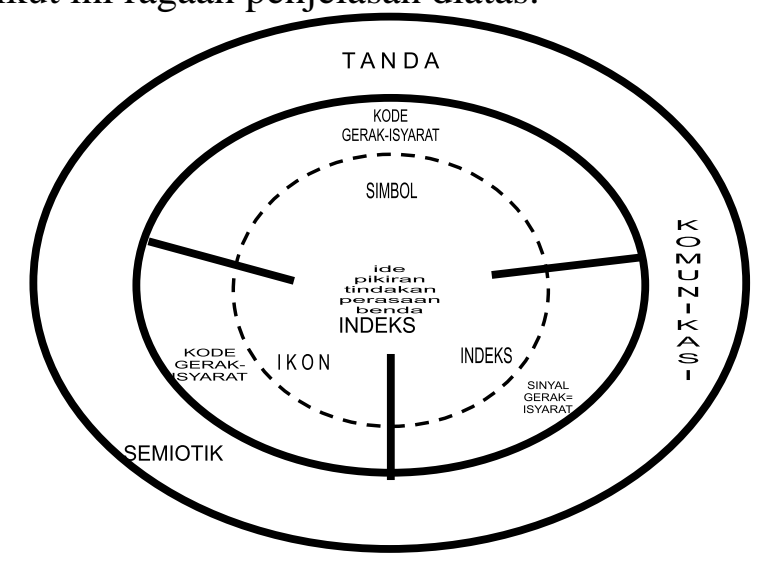

${ }^{19}$ Fromm, Erich, "The Nature of Symbolic Language”, Dalam Arthur M.Eastman (Ed.). "The Norton Reader. An Anthology of Expository Prose”, (New York: Norton and Company, 1978), hal. 194-195. 


\section{Gambar 5 \\ Ragaan Konsep Simbol Secara Semiotika Menurut Charles Sanders Peirce}

Pendekatan semiotika memerlukan penganalisis mencari penggunaan tanda-tanda dalam sesebuah karya. Tanda-tanda tersebut diungkap melalui penanda, mengikut paradoks dan kontradisksi penggunaan stail dan mekanisme penciptaan sesebuah karya yang dikuasai oleh pengarang. Maka, penganalisis menggunakan semiotik untuk memberikan makna bagi tanda-tanda dalam teks yang dikaji.

Semiotika melihat karya dalam perspektif yang lebih luas. Prinsip kedua daripada pendekatan semiotik menuntut penganalisis memperhatikan hubungan sistem sebuah teks yang dikaji dengan sistem yang ada di luar teks tersebut; yaitu segala peristiwa sejarah yang membawa kepada lahirnya teks tersebut. Ini merangkumi sistem hidup dan kebudayaan masyarakat yang menjadi sumber inspirasi penghasilan teks yang dikaji.

Segala ungkapan atau tanda-tanda yang dipaparkan dari dalam teks memainkan peranan yang penting bagi perwujudan satu bentuk sistem semiotika dalam pemaknaan teks tersebut. Maka, prinsip ketiga dalam pendekatan semiotik memberi penghargaan terhadap pengarang dan karya karangannya. Ini menjelaskan bahwa terdapat sebab bagi penggunaan setiap ungkapan yang dihasilkan dalam teks karena segalanya mempunyai pengertiannya yang tersendiri.

Salah satu kajian semiotika yang relevan dengan penelitian ini adalah semiotika normatif merupakan semiotika yang khusus membahas sistem tanda yang dibuat oleh manusia yang berwujud norma-norma. (norma agama, norma dalam etika, norma hukum dll) dan Semiotika sosial merupakan semiotika yang khusus menelaah sistem tanda yang dihasilkan manusia yang berwujud lambanglambang, baik lambang kata maupun lambang rangkaian kata /kalimat atau dalam semiotika dikategorikan sebagai semiotika struktural, yaitu semiotika yang khusus menelaah sistem tabda yang dimanifestasikan melalui struktur bahasa. Juga lambang-lambang yang disepakati oleh masyarakat atau negara/pemerintah seperti lambang negara, lambang-lambang daerah atau lambang-lambang suatu lembaga/organisasi yang didalamnya merepresentasikan ide, pikiran, benda dan tindakan manusia

\section{d. Metode Semiotika Sebagai Dasar studi Semiotika Hukum}

Berkaitan dengan konsep semiotika sebagai studi semiotika hukum, maka perlu diajukan pertanyaan apakah pengertian semiotika? terminologi semiotika atau semiologi merupakan terminologi yang berasal dari kata Yunani, 
"semeion"/Tanda"/Simbol, karena secara sederhana semiotika sering disebut sebagai "study of sign" (suatu pengkajian tanda-tanda), yang oleh Kris Budiman dan Scholes dijelaskan sebagai studi atas kodekode atau simbol-simbol, yaitu sistem apapun yang memungkinkan seseorang memandang entitas-entitas tertentu sebagai tanda-tanda atau sebagai sesuatu yang bermakna. ${ }^{20}$

Pandangan lain seperti Saussure menyebutnya sebagai ilmu umum tentang tanda, suatu ilmu yang mengkaji kehidupan tandatanda didalam masyarakat (a science that studies the life of sign within society $)^{21}$ pandangan lain adalah menurut Rahayu Surtiati Hidayat, menurutnya semiotika adalah teori dan analisis berbagai tanda (sign)/simbol (simbolic) dan pemaknaan (signification) ${ }^{22}$

Pertanyaannya berikutnya adalah apa yang menjadi studi utama Semiotika? Dengan mendasarkan pada pandangan dari Charles Moris, yaitu seorang filsuf yang menaruh perhatian atas ilmu tentang-tanda-tanda sebagaimana disitir oleh Kris Budiman menjelaskan bahwa, semiotika pada dasarnya dapat dibedakan dalam tiga cabang penyelidikan (branches of inquery), yakni sintaksis, semantik, dan pragmatik, yang dapat dipaparkan sebagai berikut: ${ }^{23}$

1) Sintaktik atau sintaksis, suatu cabang penyelidikan semiotika yang mengkaji "hubungan formal diantara suatu tanda dengan tanda yang lain”, dengan perkataan lain, karena hubunganhubungan formal ini merupakan kaidah-kaidah yang mengendalikan tuturan dan interpretasi.

2) Pengertian sintaktik kurang lebih adalah semacam metode penafsiran Gramatikal (bahasa) dalam Ilmu hukum, yaitu penafsiran yang menekan pada makna teks yang didalamnya kaidah hukum dinyatakan. Penafsiran dengan cara demikian bertolak dari makna menurut pemakaian bahasa sehari-hari atau makna teknis yuridis yang sudah dilazimkan.

Menurut Vissert Hoft, dinegara-negara yang menganut tertib hukum kodifikasi, teks harfiah undang-undang dinilai sangat penting. 3.

${ }^{20}$ Kris Budiman, "Semiotika Visual”, (Yogyakarta: Yayasan Seni Cemeti, 2003), hal.

${ }^{21}$ Ferdinand D. Saussure, "Course in General Linguistic”, (New Tork: McGraw-Hill, New York University, 1996), hal. 16.

${ }^{22}$ Rahayu Surtiati Hidayat, "Semiotik dan Bidang Ilmu, dalam Semiotika Budaya", yang disunting T. Christomy \& Untung Yuwono.(Jakarta: Pusat Penelitian Kemasyarakatan dan Budaya Direktorat Riset dan Pengabdian Masyarakat Universitas Indonesia, 2004), hal. 77.

${ }^{23}$ Kris Budiman, Op. Cit., hal. 4-5. 
Namun penafsiran gramatikal saja tidak cukup jika tentang hal yang ditafsirkan itu sudah menjadi perdebatan: ${ }^{24}$

1) Semantik, yaitu cabang penyelidikan semiotika yang mempelajari "hubungan diantara tanda-tanda dengan degsinata atau objek-objek yang diacunya". Bagi Vissert Hoft yang dimaksudkan dengan degsinata adalah makna tanda-tanda sebelum digunakan didalam tuturan tertentu;

2) Pragmatik, suatu cabang penyelidikan semiotika yang mempelajari "hubungan diantara tanda-tanda dengan interpreter atau para pemakainya-pemaknaan tanda-tanda. Pragmatik secara khusus berurusan dengan aspek-aspek komunikasi, khususnya fungsi-fungsi situasional yang melatari tuturan.

Menurut John Fiske, studi semiotika dapat dibagi kedalam tiga bagian sebagai berikut: ${ }^{25}$

1) Tanda/simbol itu sendiri, hal ini terdiri atas studi tentang berbagai tanda/simbol yang berbeda, cara tanda/simbol yang berbeda itu dalam menyampaikan makna, dan cara tanda-tanda itu terkait dengan manusia yang menggunakannya. Tanda/simbol adalah konstruksi manusia dan hanya bisa dipahami dalam artian yang menggunakannya. Menurut penukis jika dikaitkan dengan lambang negara, misalnya maka simbolsimbol yang ada pada lambang negara itu dapat dipahami dengan pemaknaan yang diberikan oleh negara terhadap makna simbol-simbol yang ada dalam lambang negara.

2) Kode atau sistem yang mengorganisasikan tanda/simbol, Studi ini mencakup cara berbagai kode dikembangkan guna memenuhi kebutuhan suatu masyarakat atau budaya atau mengekploitasi saluran komunikasi yang tersedia untuk mentransmisikannya.

3) Kebudayaan atau tempat kode dan tanda/simbol bekerja. Ini pada gilirannya bergantung pada penggunaan kode-kode dan tanda-tanda/simbol-simbol itu untuk keberadaan dan bentuknya sendiri.

Untuk memahami studi semiotika lebih mendalam, maka Yasraf Amir Pialang menjelaskan tentang beberapa elemen penting dari semiotika yang meliputi beberapa hal sebagai berikut: ${ }^{26}$

${ }^{24}$ Visser't Hoft, "Penemuan Hukum", judul asli "Rechtsvinding”, diterjemahkan oleh B. Arief Sidharta, (Bandung : Laboraturium Hukum FH Univ, Parahiayangan, 2001), hal. 25.

${ }^{25}$ John Fiske, “Cultural and Communication Studies”, (Yogyakarta: Jalasutra, 2004), hal. 60-61.

${ }^{26}$ Yasraf Amir Piliang, "Hipersemiotika; Tafsir Cultural Studies Atas Matinya Makna”, (Yogyakarta: Jalasutra, 2003), hal. 257. 
1) Komponen tanda/simbol; Apabila praktik sosial, politik, ekonomi, budaya, dan seni sebagai fenomena bahasa, maka ia dapat pula dipandang sebagai tanda/simbol. Hal ini dimungkinkan karena luasnya pengertian tanda/simbol. Meskipun demikian, didalam masyarakat informasi saat ini terjadi perubahan mendasar bagaimana "tanda/ simbol" dipandang dan digunakan. Ini disebabkan karena arus pertukaran tanda/simbol tidak lagi berpusat didalam suatu komunitas tertutup, akan tetapi melibatkan persinggungan di antara berbagai komunitas, kebudayaan dan ideologi.

2) Aksis Tanda; Analisis tanda berdasarkan sistem atau kombinasi yang lebih besar melibatkan apa yang disebut aturan pengkombinasian yang terdiri dari dua aksis, yaitu aksis paradigmatik, yaitu perbendaharaan tanda atau kata serta askis sintagmatik, yaitu cara pemilihan dan pengkombinasian tandatanda/simbol/simbol , berdasarkan aturan (rule) atau kode tertentu, sehingga dapat menghasilkan sebuah ekspresi yang bermakna.

3) Tingkatan Tanda; Barthes mengembangkan dua tingkatan penandaan, yang memungkinkan untuk dihasilkan makna yang juga bertingkat-tingkat. "Denotasi", yaitu pertandaan yang menjelaskan hubungan penanda dan petanda, atau antara tanda dan rujukan pada realitas yang menghasilkan makna yang eksplisit, langsung dan pasti. Konotasi, tingkat pertandaan yang menjelaskan hubungan antara penanda dan petanda, yang didalamnya beroperasi makna yang tidak ekspilisit, tidak langsung dan tidak pasti artinya;

4) Relasi antar Tanda: Selain kombinasi tanda analisis semiotika juga berupa berupaya untuk mengungkapkan interaksi diantara tanda-tand/simbol-simbol. Meskipun bentuk interaksi antar tanda-tanda/simbol-simbol itu sangat terbuka, akan tetapi ada dua interaksi utama yang dikenal yaitu "metafora", sebuah model interaksi tanda/simbol, yang didalamnya sebuah tanda/simbol dari sebuah sistem digunakan untuk menjelaskan makna untuk sebuah sistem yang lainnya, misalnya didalam lambang negara Indonesia ada perisai besar dan perisai kecil yang kesemuanya dibagi menjadi lima ruang yang didalamnya ada simbol-simbol yang mensimbolisasikan Pancasila, tetapi struktur letaknya dan cara membacanya dapat digunakan untuk menjelaskan sebuah sistem yang lainnya, misalnya sistem norma hukum dan keduanya ada bentuk interaksi "metafora", yaitu antara cita hukum Pancasila dan sistem norma hukum yang seharus mengacu pada metafora pembacaan cita hukum dalam dalam lambang negara. 
Berdasarkan ruang lingkup analisis semiotika di atas tentunya suatu naskah hukum dalam hal ini peraturan perundang-undangan merupakan suatu yang niscaya terlepas dari pemaknaan, karena gagasan dan semangat yang terkandung dalam suatu peraturan perundang-undangan selalu terkait dengan ruang dan waktu dalam arti sangat erat kaitannya dengan situasi dimana dan ketika peraturan perundang-undangan dirumuskan dan ditetapkan. Dalam konteks waktu, situasi seringkali mengalami perubahan karena tuntutan perkembangan masyarakat,dan karena itu sering dikatakan bahwa hukum peraturan perundang-undangan kerap mengalami ketertinggalan dimakan oleh waktu.

Menginterpretasi peraturan perundang-undangan tentu saja harus menginterpretasi atau menafsir bunyi teks-teks peraturan perundang-undangan itu sendiri, karena teks belum tentu jelas dengan sendirinya. Untuk dapat memahami teks peraturan perundang-undangan, maka harus dipelajari latar belakang sejarah terjadinya (memorie van toelichting) bunyi teks peraturan perundangundangan tersebut. Dengan mempelajari sejarah terjadinya akan dapat dipahami maksud bunyi teks oleh orang-orang yang hidup dalam konteks sejarah yang berbeda.

\section{e. Metode Penafsiran Dalam Semiotika Hukum}

Dalam studi ilmu hukum, memahami teks hukum atau peraturan perundang-undangan melalui sejarah terjadinya teks peraturan perundang-undangan tersebut merupakan salah satu cara penafsiran saja, karena masih ada beberapa teori tentang penafsiran (interpretasi) hukum lengkapnya dan metode penafsiran konstitusi yang berkembang dalam ilmu hukum pada umumnya, dan hukum tata negara pada khususnya, antara lain yang berkaitan dengan metode penelitian ini adalah sebagai berikut: ${ }^{27}$

\section{(1) Metode Penafsiran Konstruktif}

Metode penafsiran konstruktif ini, menurut Dworkin, dapat dilakukan dengan tiga tahap. Pertama, tahap pra-penafsiran dimana aturan-aturan dan batasan-batasan yang digunakan untuk memberikan isi tentatif mengenai praktik yang diperkenalkan. Kedua, adalah tahap interpretasi sendiri, dimana penafsir menjustifikasi unsur-unsur pokok yang timbul dari praktik. Justifikasi tidak perlu semua harus sesuai bagi penafsir. Menjadi sangat penting dalam hal ini, bahwa mampu melihat dirinya sendiri sebagai penafsir praktis dan menemukan sesuatu yang baru. Ketiga,

\footnotetext{
${ }^{27}$ Metode Penafsiran eksplorasi dari berbagai literatur dari ilmu Hukum dan disarikan pemetaannya oleh peneliti.
} 
setelah tahap penafsiran penafsir menyesuaikan pendiriannya tentang prakrik sebenarnya atau menyelesaikan.

\section{(2) Metode Penafsiran Konversasional}

Metode ini sebenarnya agak berada di luar kebiasaan penafsiran yang biasa digunakan. Dalam ilmu hukum. Penafsiran konversasional ini bukan dimaksudkan untuk menjelaskan pandangan seseorang. Penafsiran ini menandai makna dalam menjelaskan motif-motif dan maksud-maksud mengenai makna yang dirasakan pembicara dalam hal ini perancang tanda sebagai katagori simbol, dan menyimpulkan sebagai pernyataan tentang maksud pembicaraan atau makna perancangan dalam mengatakan apa yang dia perbuat. Penafsir hendak menemukan maksud atau makna yang diucapkan oleh orang lain dalam berbagai peristiwa yang secara tepat untuk makna yang berkembang dalam masyarakat, misalnya pernyataan "politisasi hukum", "kriminalisasi kasus", "Elang Rajawali-Garuda Pancasila". Soetandyo ${ }^{28}$ dalam salah satu tulisannya semiotika, mengatakan tentang the legal semiotics, semiotic jurisprudence. Semiotik mengkaji tentang tanda-tanda kebahasaan yang tidak lain dari hasil konseptualisasi oleh subjek-subjek atau intersubjek

Ketika ide, pemikiran, konsep, perasaan dan tindakan itu diverbalkan, maka sebuah simbol yang telah termaknakan tersebut diformulasikan kedalam bahasa teks hukum dan jika teks hukum itu dikonstruksi dalam sebuah bentuk hukum, misalnya yang dikeluarkan oleh lembaga yang berwenang atau pejabat yang berwenang, maka selanjutnya dinamakan peraturan perundang-undangan.

Pada tataran inilah peraturan perundang-undangan pada studi semiotika hukum bukan hanya dibaca secara teks an sic, tetapi harus dieksplanasi ide, pemikiran, konsep, perasaan dan tindakan apa yang menyelinap kedalam rumusan teks peraturan perundang-undangan atau ide, pemikiran, konsep, perasaan dan tindakan yang tersurat dan tersirat dibalik teks hukum dalam formulasi materi muatan peraturan perundang-undangan.

Dengan demikian teks hukum telah dikonsepkan kedalam beberapa ragam makna yang kemudian pada tataran realitas, teks hukum akan dipersepsi

28 Soetandyo Wignjosoebroto, "Hukum Paradigma, Metode dan Masalah", (Jakarta: ELSAM dan HUMA, 2010), hal, 15. Legal Semioticsatau Semiotic Jurisprudence: Sebagai Metode Analisis atau Aliran Teori Baru dalam Ilmu Hukum.Analisis dari perspektif semiotika adalah salah satu contoh realisme dalam pemikiran dan analisis hukum, baik pada tataran paradigmatis-teoretis maupun pada tataran produk legislatif dan kasus-kasus konkretnya di sidang-sidang pengadilan. Analisis-analisis semiotika memang diprakarsai oleh para realis yang memulai aktivitasnya dalam bentuk gerakan-gerakan sosial-politik untuk melakukan pembaruan dalam tatanan sosial dan tatanan hukum, dan baru kemudian disusul oleh gerakan-gerakan yang lebih bersifat akademis dalam bentuk dekonstruksi-rekonstruksi paham dan teori dalam percaturan ilmu hukum. Semiotika Hukum dianggap sebagai paradigma baru yang nonpositivistis dan nondoktrinal, yang harus diawalmulakan sebagai gerakan sosialpolitik guna melakukan dekonstruksi-dekonstruksi dalam ilmu hukum. 
dari berbagai perspektif, dan kemudian daripada itu akan menghasilkan pemahaman, pemaknaan, dan konsep yang tak bisa tunggal. "Hukum bukanlah lagi sebatas gejala atau realitas; melainkan sebuah konsep yang dapat dieksplanasi dari berbagai cara pandang pemikir dan penstudi hukum sesuai dengan paradigma yang diacu oleh pemikir dan penstudi hukum bersangkutan.

Mengapa demikian? Karena sejak hukum membuat tradisi untuk dituliskkan (written law), maka pembacaan terhadap teks hukum menjadi masalah yang penting sekali. Sejak pembacaan teks menjadi penting, maka penafsiran terhadap teks hukum tak dapat dihindarkan. Bahkan menurut Satjipto Rahardjo mengatakan, bahwa penafsiran hukum itu merupakan jantungnya hukum. Hampir tidak mungkin hukum bisa dijalankan tanpa membuka pintu penafsiran.

Penafsiran hukum merupakan aktivitas yang mutlak terbuka untuk dilakukan, sejak hukum berbentuk tertulis. Diajukan sebaih adagium "membaca hukum adalah menafsirkan hukum". Jadi jika ada yang menyatakan bahwa teks hukum sudah jelas ketika diverbalkan kedalam bentuk hukum tertulis, misalnya dalam formulasi peraturan perundang-undangan menurut Satjipto Rahardjo adalah satu cara saja bagi pembuat hukum untuk bertindak pragmatis seraya diam-diam mengaku bahwa ia mengalami kesulitan untuk memberikan penjelasan. ${ }^{29}$

Sebagaimana kita ketahui, bahwa penafsiran hukum (di Indonesia) selama ini didominasi oleh metode-metode positivistik, dengan tidak memberikan ruang dialog kepada metode alternatif. Pembacaan terhadap hukum tersebutr apabila kita mengambil pandangan Ali Harb, "telah menimbulkan pembatasan penafsiran, penafsiran yang lebih berorientasi kepada kepastian, yang jelas, yang tetap (rigid), atau mengarah kepada penafsiran yang kakuy dan memaksakan bentuk-bentuknya. Oleh karena itu, dalam model penafsiran tersebut, tujuan rekonstruksiu teks adalagh mereduksi teks tersebut. Bahkanpada setiap rekonstruksi akhir itu identik dengan karakter normatif dogmatis atau irasional. ${ }^{30}$

Dengan demikian menafsirkan bukan hanya merupakan analisis, tetapi juga merelasikan, bukan hanya membagi suatu keutuhan ke dalam uraian parsial, tetapi juga menyimpulkan bagian-bagian teks ke dalam suatu pandangan global. Dengan kata lain, menafsirkan adalah mencari hakekat sesuatu. Menafsirkan adalah menemukan sesuatu yang baru antara bahasa teks dengan realitas.

Selama ini penafsiran dalam positivisme hukum ${ }^{31}$ melihat adanya hubungan hirarki dan dominasi antara penafsir dengan yang ditafsirkan, ada

${ }^{29}$ Satjipto Rahardjo, "Penafsiran Hukum Yang Progresif", Pra wacana dalam Anthon Freddy Susanto, "Semiotika Hukum dari Dekontruksi Teks menuju Progresivitas Makna", (Bandung: Refika Pratama, 2005), hal. 1.

${ }^{30}$ Ali Harb, "Relativitas Kebenaran”, (Yogyakarta: IRCiSod, 2001), hal. 43.

${ }^{31}$ Positivisme Hukum adalah Aliran pemikiran dalam hukum yang membahas konsep hukum secara ekslusif dan berakar pada peraturan perundang-undangan yang berlaku saat ini. 
pemisahan subjek (penafsir) dengan objek (yang ditafsirkan), dasarnya tidak lain adalah silogisme hukum yang didasarkan kepada premis-premis normatif.

Untuk menjelaskan hal ini dapat dicontohkan ketika bangsa Indonesia menyebut bahwa gambar lambang negara Indonesia adalah figur burung garuda sebagaimana dalam mitologi, maka opini umum terbentuk, bahwa gambar lambang negara Indonesia adalah figur burung garuda seperti yang digambarkan dalam mitologi bangsa Indonesia, khsususnya mitologi hindu, sebagaimana digambarkan dalam Peraturan Pemerintah Nomor 66 Tahun 1951 tentang Lambang Negara dan Undang-Undang Nomor 24 Tahun 2009 Tentang Bendera, Bahasa dan Lambang Negara serta Lagu Kebangsaan.

Penjelasan Peraturan Pemerintah Nomor 66 Tahun 1951 Tentang Lambang Negara yang menyatakan:

Lukisan Garuda diambil dari benda Peradaban Indonesia seperti hidup dalam Mityologi, symbologi dan Kesusasteraan Indonesia dan seperti pula tergambar pada beberapa candi sejak abad ke 6 sampai abad ke 16. (Penjelasan Pasal 1)

"Burung Garuda dari mytologi menurut perasaan Indonesia berdekatan dengan burung Elang Rajawali. Burung itu dilukiskan di candi Dieng, Prambanan dan Penataran. Ada kalanya dengan memakai lukis berupa manusia dengan berparuh burung dan bersayap (Dien): dicandi Prambanan dan di candi Jawa Timur seperti berparuh panjang berambut raksasa dan bercakar. Lihatlah lukisan garuda dicandi mendut, Prambanan dan candi-candi Sukuh.Kedal di Jawa Timur.Umumnya maka garuda terkenal baik oleh archeologi, kesusasteraan dan mitologi Indonesia.Lencana Garuda pernah dipakai oleh prabu Air Langga pada abad kesebelas dengan bernama Garudamukha.Menurut patung Belahan beliau dilukiskan dengan mengendarai seekor garuda.

Kemudian pada teks hukum negara pada pasal 1 dan Pasal 3 Peraturan Pemerintah Nomor 66 Tahun 1951 menyatakan:

Lambang Negara Republik Indonesia terbagi atas tiga bagian yaitu: 1. Burung Garuda yang menengok dengan kepalanya lurus kekanannya;

Pasal 3

Garuda yang digantungi perisai dengan memakai patruh, sayap, ekor dan cakar mewujudkan lambang tenaga pembangun. Sayap Garuda berbulu 17 dan ekornya berbulu 8. Warna, perbandingan-

Positivisme hukum dimaknai pula sebagai sebuah teori yang menyatakan bahwa hukum akan valid jika berbentuk norma-norma yang dapat dipaksakan berlakunya dan ditetapkan oleh sebuah instrumen di dalam sebuah negara. 
perbandingan ukuran dan bentuk Garuda adalah seperti dilukiskan dalam gambar tersebut dalam Pasal 6.

Kemudian jika membaca teks hukum negara pada pasal 6 Peraturan Pemerintah No 66 Tahun 1951 menyatakan:

Bentuk warna dan perbandingan ukuran Lambang Negara Republik Indonesia adalah seperti terlukis dalam lampiran pada Peraturan Pemerintah ini.

Demikian juga dalam teks hukum pada Pasal 46 dan penjelasannya Undang-Undang Nomor 24 Tahun 2009 Tentang Bendera, Bahasa, dan Lambang Negara Serta Lagu Kebangsaan dalam Penjelasan 46 menyatakan:

Lambang Negara Kesatuan Republik Indonesia berbentuk Garuda Pancasila yang kepala menoleh lurus kesebelah kanan, perisai berupa jantung yang digantung dengan rantai pada leher Garuda, dan semboyan Bhinneka Tunggal Ika ditulis diatas pita yang dicengkram oleh Garuda.

Yang dimaksud dengan "Garuda Pancasila" adalah Lambang berupa burung garuda yang sudah dikenal melalui mitologi kuno, yaitu burung yang menyerupaiBurung Elang Rajawali.

Pasal 50

Bentuk warna dan perbandingan ukuran Lambang Negara sebagaimana dimaksud dalam Pasal 46 sampai dengan Pasal 49 tercantum dalam lampiran yang tidak terpisahkan dari Undangundang ini.

Pertanyaan secara semiotika hukum, apakah gambar lukisan yang dimaksud Pasal 1, 3 dan Pasal 6 Peraturan Pemerintah Nomor 66 Tahun 1951 dan Pasal 46 jo Pasal 50 Undang-Undang Nomor 24 Tahun 2009, adalah lukisan burung Garuda Pancasila sebagaimana dimaksud dalam mitologi, sastra, simbologi Indonesia. Menurut analisis semiotika hukum, bahwa bentuk lukisan yang menjadi lampiran Peraturan Pemerintah Nomor 66 Tahun 1951 dan Undang-Undang Nomor 24 Tahun 2009, adalah bukan lukisan berupa burung Garuda sebagaimana dimaksud dalam mitologi, tetapi bentuk gambarnya adalah burung Elang Rajawali, karena bentuk figur lukisan burung Garuda sebagai rancangan tahap pertama Sultan Hamid II yang diajukan kepada Panitia Lambang Negara 8 Februari 1950 yang sudah dikritik oleh anggota Panitia, yakni Muhammad Natsir atau sudah diperbaiki dan disempurnakan oleh Sultah Hamid II. Dengan perkataan lain sudah bergeser dari figur burung Garuda ke figur burung Elang Rajawali sebagaimana pada perancangan tahap kedua. 
Selanjutnya bagaimana pandangan Presiden Soekarno dalam penyebutan lambang negara Republik Indonesia yang bentuk gambarnya seperti sekarang ini? Presiden Soekarno dalam Pidato Kenegaraan 22 Juli 1958menyatakan secara tegas:

Saudara-saudara, Lihatlah Lambang Negara kita dibelakang ini alangkah megahnya, alangkah hebat dan cantiknya.Burung Elang Rajawali, garuda yang sayap kanan dan sayap kirinya berelar 17 buah, ekor yang berelar 8 buah, tanggal 17, bulan 8 dan berkalungkan perisai yang diatas perisai itu tergambar Pancasila.....

Presiden Soekarno menyebut lambang negara dengan nama Burung Elang Rajawali.Bahkan Muhammad Yamin sendiri sebagai bekas Ketua Panitia Lambang Negara 1950 dalam bukunya Pembahasan Undang-Undang Dasar 1945, halaman 144 yang menyatakan: ${ }^{32}$

Jadi Burung sakti Elang Rajawali sebagai lambang pembangunan dan pemelihara diseluruh bangsa Indonesia...."Seperti diperhatikan maka latar lambang itu terbagi atas tiga bagian, yaitu lukisan Elang Rajawali, perisai Pancasila dan seloka Empu Tantular.

Burung sakti Elang Rajawali dilukiskan dengan 17 sayap terbang, 8 helai sayap emudi dan 45 helai buku sayap sisik pads tubuh. Perlambangan ketiga angka itu ialah lukisan cendra sengkala: 17 Agustus 1945, yaitu hari Proklamasi Kemerdekaan Indonesia

Penelusuran dari literatur akademik yang lain Soediman Kartohadiprojo, juga menyatakan: ${ }^{33}$

Lambang Ngara kita terdiri dari tiga bagian: (1) Candra Sengkala, (2) Perisai Pancasila, (3) Seloka Bhinneka Tunggal Ika. Candra Sengkala ini terdapat dalam "burung sakti Elang Rajawali (cetak tebal dari penulis) yang bulu sayapnya 17 helai jumlahnya, bulu sayap kemudinya 8 helai, sedangkan bulu sayap sisiknya pada batang tubuhnya berjumlah 45 ini melukiskan hari diproklamasikan Republik Indonesia.

Sultan Hamid II kepada wartawan Solichin Salam, 15 April 1967: ${ }^{34}$

\footnotetext{
32 Muhammad Yamin, "Pembahasan Undang-Undang Dasar 1945", (Jakarta: Prapanca,1967), hal. 144.

${ }^{33}$ Soediman Kartohadiprojo, "Pancasila sebagai Pandangan Hidup Bangsa Indonesia", (Jakarta: Gatra Pustaka, 2010), hal. 229.
} 
..Akhirnya setelah penolakan itu saja mengambil inisiatif pribadi untuk memperbandingkan dengan lambang-lambang negara luar, khususnja negara negara Arab, seperti Yaman, Irak, Iran, Mesir ternjata menggunakan figur burung Elang Radjawali, djuga seperti negara Polandia jang sudah lama ratusan tahun djuga menggunakan burung Elang Radjawali seperti jang saja djelaskan di atas dalam kemiliterannja, setelah saja selidiki ternjata bendera perang Sadjina Ali r.a ternjata memakai pandji-pandji simbol burung Elang Radjawali, untuk itulah saja putuskan mengubah figur burung dari mitologi garuda ke figur burung elang Radjawali....

...latar belakang gambar jang saja tjiptakan pertama mengambil figur burung Garuda memegang perisai Pantja-Sila berubah mendjadi figur Burung Elang Radjawali yang dikalungkan perisai Pantja-Sila agar proses bangsa ini djangan melupakan peradaban bangsanja dari mana dia berasal/djangan sampai melupakan sedjarah puntjak-puntjak peradabannja, seperti pesan Paduka Jang Mulia....

Berdasarkan pernyataan dalam literatur dan teks hukum negara di atas jika dihubungan dengan pendekatan semiotika hukum dengan membandingkan dua dokumen gambar pada rancangan lambang negara Republik Indonesia tahap pertama dan rancangan lambang negara Republik Indonesia tahap kedua ternyata realitas empirik telah terjadi pergeseran semiotika lambang negara, yaitu dari figur burung garuda ke figur elang Rajawali. Terhadap fakta sejarah ini ternyata dalam paparan sejarah hukum lambang negara tidak pernah muncul kepermukaan.

Untuk membuktikan pergeseran semiotika lambang negara, maka dapat diperhatikan dalam dokumen urutan gambar file lambang negara yang dibuat/dirancang oleh Sultan Hamid II dari tanggal 8 Februari 1950 s/d 11 Februari 1950 berikut ini:

\footnotetext{
${ }^{34}$ Penjelasan dalam Transkrip Sultan Hamid II kepada Solichin Salam, 15 April 1967 sebagaimana ditulis kembali Max Yusuf Al Kadrie sekretaris Pribadi Sultan Hamid II.
} 


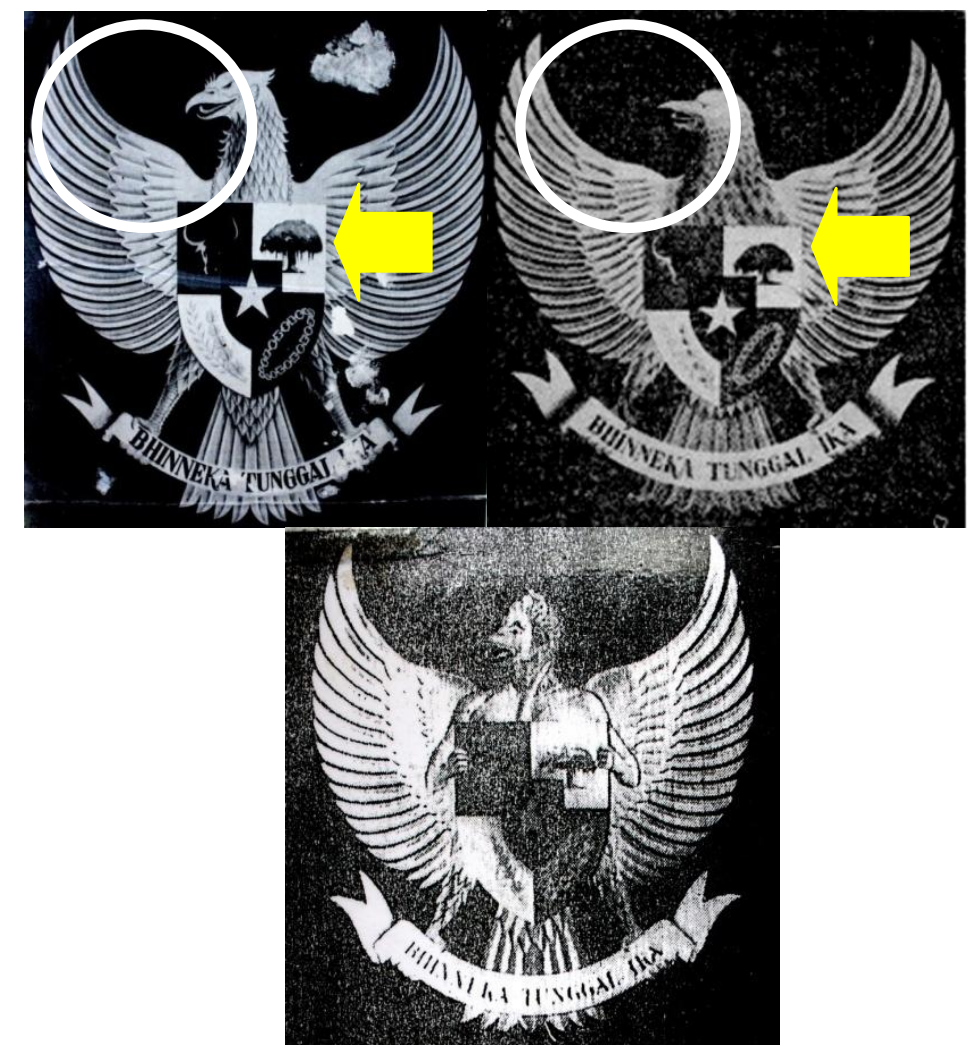

Gambar 1

Tiga dokumen Gambar Lambang Negara Republik Indonesia dengan dua figur burung yang berbeda pada gambar yang pertama mengambil figur burung Garuda dalam mitologi bangsa Indonesia dan dua gambar berikutnya mengambil figur burung elang Rajawali, perhatikan bentuk kepala dan cakar kaki burung tersebut terlihat menghadap kebelakang (Sumber : Max Yusuf Akadrie Yayasan Sultan Hamid II, Jakarta, Dan Yayasan Mas Agung, Jakarta, 2011)

Pertanyaan yang perlu diajukan dengan mengacu pada dokumen di atas dan teks hukum negara yang tertulis dalam peraturan perundangan serta pernyataan Presiden Soekarno, Sultan Hamid II, Muhammad Yamin, dan Soediman Kartohadprojo yaitu apakah gambar lambang negara Republik Indonesia saat ini mengambil lukisan figur burung Garuda dalam mitologi atau mengambil lukisan figur burung Elang Rajawali?

Jawaban atas pertanyaan itu memberikan sebuah refleksi dari pendapat umum yang menyatakan, bahwa lambang negara republik Indonesia adalah berupa burung Garuda atau dalam bahasa hukum Undang-Undang Nomor 24 Tahun 2009 pada penjelasan pasal 46 "yang dimaksud dengan "Garuda Pancasila" adalah Lambang berupa burung garuda yang sudah dikenal melalui mitologi kuno", yaitu burung yang menyerupai Burung Elang Rajawali. Atau dalam bahasa konstitusi UUD 1945 hasil amandemen menyatakan, bahwa lambang negara ialah Garuda Pancasila dengan semboyan Bhinneka Tunggal $\mathrm{Ika}^{35}$. Sedangkan secara analisis semiotika

\footnotetext{
${ }^{35}$ Pasal 36 A UUD Neg Ri 1945 hasil amandemen kedua.
} 
hukum figur lambang negara yang dipilih berdasarkan fakta sejarah hukum adalah figur burung elang Rajawali. Ini memberikan bukti bahwa antara fakta sejarah dengan yang dirumuskan oleh teks hukum negara berbeda atau antara teks hukum dan yang menjadi lampiran peraturan perundang-undangan berbeda bentuk gambar lambang negara yang dimaksud.

Secara semiotika hukum, jika yang dimaksudkan pada teks hukum negara (Pasal 46 Undang-Undang Nomor 24 Tahun 2009) atau Pasal 1 jo Pasal 3 Peraturan Pemerintah Nomor 66 Tahun 1951 adalah Lambang Negara Republik Indonesia berbentuk Garuda Pancasila yang kepala menoleh lurus kesebelah kanan, perisai berupa jantung yang digantung dengan rantai pada leher Garuda, dan semboyan Bhinneka Tunggal Ika ditulis di atas pita yang dicengkram oleh Garuda, maka bentuk gambar lukisan dimaksud adalah bukanlah gambar garuda yang dimaksudkan dalam mitologi garuda atau berupa burung garuda yang sudah dikenal melalui mitologi kuno" seperti gambar lambang negara rancangan pertama Sultan hamid II berikut berikut ini;

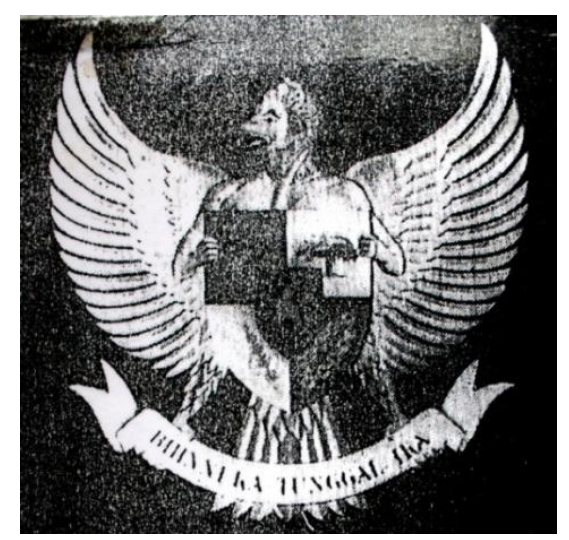

\section{Gambar 2 \\ Lambang Negara Figur Burung Garuda}

Makna secara hermenuetika historis memberikan paparan, bahwa setiap realitas kenegaraan dalam kaitannya dengan lambang negara yang ada pada saat ini telah terjadi sebuah pemahaman yang terekonstruksi dari pandangan mitologi, yaitu mitologi Garuda. Sehingga secara teks hukum negara menjadi bias pemahaman, karena dengan memberikan klasul "kepala menoleh lurus kesebelah kanan, perisai berupa jantung yang digantung dengan rantai pada leher Garuda, dan semboyan Bhinneka Tunggal Ika ditulis di atas pita yang dicengkram oleh Garuda, maka secara semiotika yang dimaksudkan adalah figur burung garuda yang sudah berubah menjadi figur burung Elang Rajawali. Mengapa demikian? karena bentuk gambarnya adalah figur burung Elang Rajawali. Hal ini bisa diperhatikan pada semiotika perubahan bagian kepala yang semula model kepala garuda dalam mitologi, berubah menjadi kepala elang Rajawali.

Pada bagian lain perisai Pancasila tidak lagi dipegang lengan manusia seperti yang digambarkan burung garuda dalam mitologi, tetapi digantung dengan rantai pada leher Garuda (Elang Rajawali), atau meminjam penjelasan 
Peraturan Pemerintah Nomor 66 Tahun 1951 adalah "Burung Garuda dari mytologi menurut perasaan Indonesia berdekatan dengan burung Elang Rajawali" atau lebih tegas lagi dalam penjelasan Pasal 46 Undang-Undang Nomor 24 Tahun 2009: "Yang dimaksud dengan "Garuda Pancasila" adalah Lambang berupa burung garuda yang sudah dikenal melalui mitologi kuno, yaitu burung yang menyerupai Burung Elang Rajawali.". Oleh karena itu secara semiotika hukum Sultan Hamid II menyatakan secara cerdas dalam transkripnya sebagai berikut: ${ }^{36}$

...sedangkan mengapa diberi nama Burung Elang Radjawali Garuda Pantja-Sila, karena saja menghargai latar belakang gambar jang saja tjiptakan pertama mengambil figur burung Garuda memegang perisai Pantja-Sila,berubah mendjadi figur Burung Elang Radjawali jang dikalungkan perisai Pantja-Sila agar proses bangsa ini djangan melupakan peradaban bangsanja dari mana dia berasal/djangan sampai melupakan sedjarah puntjak-puntjak peradabannja, seperti pesan Paduka Jang Mulia.

Kemudian pada bagian lain menyatakan: ${ }^{37}$

Saja sedjudjurnya hanya berupaja mengangkat kembali lambanglambang/simbol-simbol jang ada di peradaban klasik bangsa Indonesia bersama anggota Panitia Lambang Negara itu sebenarnya semangat gorong-royong lewat perentjanaan gambang Lambang Negara RIS sebagaimana ditugaskan kepada saja selaku Menteri Zonderportofolio. Karena memang tidak ada tugas lain untuk saja sebagai Menteri Selain merentjanakan lambang negara dan menjiapkan gedung parlemen RIS, saja berharap agar kelak bangsa ini ditjintai oleh kita semua bertekad untuk memadjukanmembangun bersama.

Berdasarkan pernyataan Sultan Hamid II dan pernyataan Presiden Soekarno dalam pidato 22 Juli 1958, dan Muhammad Yamin, Soediman Kartohadiprojo dalam tulisannya, maka lambang negara yang dimaksud sebagai bentuk gambar lukisan burung Elang Rajawali adalah sebagaimana bentuk gambarnya berikut ini;

\footnotetext{
36 Transkrip Sultan Hamid II, kepada wartawan Solichin Salam, yang disalin kembali oleh sekretaris pribadi Sultan Hamid II Max Yusuf Al-Kadrie, 15 April 1967, hal. 6.

37 Transkrip Sultan Hamid II, kepada wartawan Solichin Salam, yang disalin kembali oleh sekretaris pribadi Sultan Hamid II Max Yusuf Al-Kadrie, 15 April 1967, hal. 9.
} 


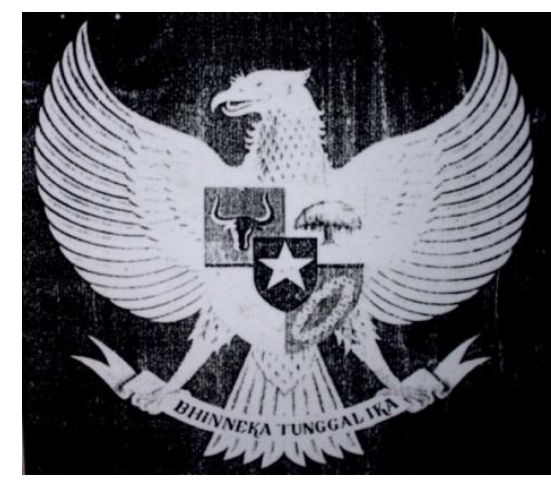

Gambar 3

Lambang Negara Figur Burung Elang Rajawali

Pernyataan-pernyataan di atas tentunya ada pesan filosofis, bahwa bangsa Indonesia melalui lambang negara yang lukisannya diambil dari lukisan Garuda dalam mitologi yang terdapat dalam peradaban bangsa Indonesia tidak menjadikan bangsa Indonesia melupakan peradaban bangsanya, namun dengan mengambil figur burung elang Rajawali seperti lambang negara yang di dunia mengandung pesan untuk memajukan bangsanya selaras dengan peradaban dunia dan bernilai universal. Jadi menurut penulis perlu dilakukan pembongkaran (dekonstruksi) terhadap mitos lambang negara Republik Indonesia, karena tidak sesuai dengan fakta sejarah hukum lambang negara Republik Indonesia dan terkesan ada sesuatu yang "disembunyikan" oleh negara, bahwa sebenarnya ada dua tahap perancangan lambang negara oleh Sultan Hamid II.

Seharusnya secara semiotika hukum dan fakta sejarah hukum dengan melihat bukti dokumen file lambang negara yang bentuknya seperti sekarang ini, teks hukum negara itu patut

\section{Penutup}

Derrida sebagai contoh postsrukturalisme mencoba menawarkan metode dekonstruksi untuk mengatasi problem moderinitas. Sasaran dekonstruksinya ditujukan untuk membongkar sifat totaliter dari metafisika dan epistemologi Barat yang selama ini didominasi oleh logosentrisme dan metafisika kehadiran sehingga harus didekontruksi. Serangan dekonstruksi Derrida membebaskan dua konsep tirani yang mendominasi filsafat, yaitu konsep totalitas dan esensi, sehingga menghasilkan kebenaran yang plural, unik dan relatif. Dengan demikian, keberanekaan diakui keberadaannya. Kesulitan yang dihadapi Derrida adaklah dia akan terjebak dalam ambiguitas yang mengarah pada nihilisme.

Salah satu yang paling sulit untuk dipahami adalah dekonstruksi yaitu strategi untuk mengurai teks. Dekonstruksi adalah sebuah istilah yang digunakan untuk menerangkan lembaran baru filsafat, strategi intelektual, atau 
model pemahaman. Jadi memahami dekonstruksi sama saja memahami Derrida yang membingungkan, karena terdapat ketidak sejajaran antar ide ide dekonstruksi pada strategi intelektual dengan dekonstruksi pada tingkat estitika.

Istilah dekonstruksi sendiri sebenarnya penictionary, dijelaskan pengertian analisis sebagai the separating of any material or abstract entity into its constitutent elements. Ini mirip dengan pengertian deconstruct, yang berarti to break down into constituent parts. Menurut Al Fayyadl, kedekatan etimologis struktur dan medan pemaknaan dalam teks ketimbang operasi yang merusak teks itu sendiri. ${ }^{38}$

Jadi dekonstruksi Derrida ketika dihubungkan dengan teks hukum sebenarnya adalah pemaknaan dibalik teks dan berupaya menemukan makna asli dibalik rumusan pasal-pasal dengan membongkar realitas yang mendasari dirumuskannya rumusan pasal-asal dalam teks hukum, sehingga menemukan makna asli.

${ }^{38}$ Muhammad Al Fayyadl, "Derrida”, (Yogyakarta: LkiS, 2005), hal. 80. 


\section{Daftar Pustaka}

\section{Buku}

Harb, Ali. Relativitas Kebenaran, Yogyakarta: IRCiSod, 2001.

Susanto, Anthon Freddy. Semiotika Hukum dari Dekontruksi Teks menuju Progresivitas Makna, Bandung: Refika Pratama, 2005.

Bartens, K. Filsafat Abab XX Perancis, jilid II, Jakarta: PT Gramedia, 1990.

Fiske, John. Cultural and Communication Studies, Yogyakarta: Jalasutra, 2004.

Derrida, Jaques. L'ecriture et la Diffrence, terjemahan Alan Bass, Writing and Diffrence, Chicago: The University of Chicago Press, 1978.

Hardiman, F. Menuju Masyarakat Komunikatif: Ilmu Masyarakat, Politik dan Postmodernisme Jurgen Habermas, Yogyakarta: Kanisius, 1993.

Yamin, Muhammad. Pembahasan Undang-Undang Dasar 1945, Jakarta: Prapanca, 1967.

Piliang, Yasraf Amir. Hipersemiotika Tafsir Cultural Studies Atas Matinya Makna, Yogyakarta: Jalasutra, 2003

Sugiharto, Bambang. I, Postmodernisme Tantangan bagi Filsafat, Yogyakarta: Kanisius, 1996.

Kartohadiprojo, Soediman. Pancasila sebagai Pandangan Hidup Bangsa Indonesia. Jakarta: Gatra Pustaka, 2010.

Wignjosoebroto, Soetandyo. Hukum Paradigma, Metode dan Masalah, Jakarta: ELSAM dan HUMA, 2010 .

\section{Jurnal}

Hadiwinata, Bob Sugeng. "Theatrum Politicum: Postmodernisme" dan Kritis Kapitalisme Dunia”, Dalam Jurnal Kebudayaan KALAM, No. 1, Th 1994, Yayasan Kalam dan Penerbit Pustaka Grafiti, Jakarta.

Sahal, Ahmad. "Kemudian dimanakah Emansipasi? Tentang Teori Kritis , Geneologi, dan Dekonstruksi", Dalam Jurnal Kebudayaan KALAM, No 1 th 1994, Yayasan Kalam dan Penerbit Pustaka Grafiti, Jakarta.

\section{Majalah}

Santoso, A. Hendra. "Postmodernisme: Kritik atas Sains dan Filsafat Modern”, Dalam Majalah Filsafat DRIYARKARA, Th. XIX, No. 4, 1992/1993, STF Driyarkarsa, Jakarta. 